\title{
Genius and Common Sense: The Romantics and Leigh Hunt
}

\section{A V I D Q. S M I T H}

A wonderfully apt, succinct characterization of Leigh Hunt appears in a recent popular literary history: "Leigh Hunt (1784-1859) was a gifted and industrious man of letters, who spent much of his working life in the company of men of genius." 1 A better brief estimation would be hard to find, but it points to a special problem. How does one write about an author whose work was done more than a century ago if that writer was not himself a genius? How do you talk about a man of considerable talent who, it is asserted, never wrote anything absolutely of the first rank but whose work you nevertheless wish to commend? In reading the scholarly critical literature on Hunt, again and again one finds condemning, or at best apologetic, assessments. "[Hunt's criticism] lacks theoretical power, as his loose derivative theory of the imagination shows. He has little judgment. . . . However important as a middleman of romantic ideas and tastes,... he lacks real distinction of mind." "Hunt [employing the critical vocabulary of romanticism] is using these terms for the emotional aura that surrounds them, and all precision of meaning is lost." "We should acknowledge at the outset... that Hunt's intellectual faculties for synthesis were not of the first order and that he was not especially interested in theoretical matters." 4 One has to sympathize with the scholars who have come to these assessments because a fair judgment must discriminate, and in the comparison with his great contemporaries, Shelley, Wordsworth, Coleridge, Hazlittgeniuses all-Hunt is left behind. If that is the case, however, why do we bother to remember him?

\footnotetext{
${ }^{1}$ Peter Quennell, A History of English Literature (London: Ferndale Editions, 1981), p. 380

${ }^{2}$ Rene Wellek, A History of Modern Criticism: 1750-1950, 4 vols. (New Haven and London: Yale University Press, 1955-65), vol. 3: The Age of Transition, p. 125.

${ }^{3}$ Stephen F. Fogle, "Leigh Hunt and the End of Romantic Criticism," in Some British Romantics, ed. James V. Logan, John E. Jordan, and Northrop Frye (Columbus: Ohio State University Press, 1966), p. 128.

${ }^{4}$ James R. Thompson, Leigh Hunt (Boston: Twayne Publishers, 1977), p. 106.
} 
In saying that Hunt was not a genius in the way that his great contemporaries were, I was thinking of Hazlitt's discussion in the essays "On Genius and Common Sense" that appeared in Table Talk (1821). If we cannot praise Hunt for his genius, we can perhaps praise him for his common sense and, by studying the term and his embodiment of it, appreciate a quality, important to the romantic critics, that is by no means contemptible, nor even always easily achieved. Approaching him in this vein, we may approximate the view held by his great contemporary admirers. Shelley, for instance, dedicated The Cenci to Hunt thus: "Had I known a person more highly endowed than yourself with all that it becomes a man to possess, I had solicited for the work the ornament of his name.... One of simpler, and, in the highest sense of the word, of purer life and manners I never knew." When a writer as serious in his ideals as Shelley speaks this way, saying he uses his words "in the highest sense," we know he doesn't simply mean that Hunt is a pleasant man without notable vulgarities of manner or motive. Hazlitt, too, has judicious but high praise for Hunt. In The Spirit of the Age (1825) he notes the faults in Hunt's writing, which are that "he perhaps takes too little pains, and indulges in too much wayward caprice." But he also says, "He is the only poet or literary man we ever knew who... united rare intellectual acquirements with outward grace and natural gentility." Furthermore "a wit and a poet, Mr. Hunt is also distinguished by fineness of tact and sterling sense." ${ }^{6}$ Compare this praise with a sentence from the first essay "On Genius and Common Sense": "Tact, finesse, is nothing but the being completely aware of the feeling belonging to certain situations, passions, $\& \mathrm{c}$. and the being consequently sensible to their slightest indications or movements in others." ${ }^{7}$ Hazlitt uses this sentence to introduce his culminating example of the quality of common sense, Lord Shaftesbury's discovery of Anne Hyde's secret marriage to the Duke of York from subtle changes in her mother's bearing toward her. "This," Hazlitt concludes, "was carrying the prophetic spirit of common sense as far as it could go." If we consider Hazlitt's remarks carefully, it thus seems that something akin to the "prophetic spirit of common sense" is one of the "rare intellectual acquirements" he attributes to Hunt when praising his "fineness of tact and sterling sense."

So far as "prophetic spirit" goes, even Hunt's severest detractors agree that he had an uncanny ability to discover and encourage young poetic

\footnotetext{
${ }^{5}$ These essays are conveniently reprinted by John R. Nabholtz, ed., William Ilazlitt: Selected Essays (New York: Appleton-Century-Crofts, 1970), pp. 18-43.

${ }^{6}$ William Hazlitt, The Spirit of the Age: or Contemporary Portraits, introduced by A. R. Waller (New York: E. P. Dutton, 1910, 1955), p. 343.

${ }^{7}$ Nabholtz, p. 30.
} 
talent. Stephen F. Fogle, for instance, recognizing Hunt's great contributions to practical criticism, says, "To have brought out in The Examiner, one of the most influential papers of the day, the first published work of John Keats, and to have used its power to assist both Keats and Shelley is an act of prescience from which nothing can detract." ${ }^{8}$ Amy Lowell earlier created the phrase that subsequent writers have seized as the most favorable and least controversial judgment they could make concerning Hunt's critical achievement, though even she feels obliged to disclaim any illusions that he was greater than he should be: "Hunt was not a great creator certainly, but he was a great introducer. . . I can never forget that it was his Imagination and Fancy which first taught me what poetry was. There is no better text-book for the appreciation of poetry than that volume." James B. Misenheimer, Jr. elaborates on Lowell's concept of "introducer," in a similarly defensive way:

Although his own creative powers were not great, his appreciation of creative ability in others was wide and sound.... Hunt had an almost uncanny power to single out good poets and good works and to make independent evaluations that would stand the test of time. ${ }^{10}$

But when Hazlitt referred to the "prophetic spirit of common sense" he surely meant something other than a good record of accurate prediction. Among the liberal romantics of Hunt's acquaintance, the notion of prophecy had a special force. Let us consider Shelley's use of the term in his "Defence of Poetry" which, like Hazlitt's essay "On Genius and Common Sense," first appeared in the world in 1821, the crucial year in which Hunt began his Italian adventure and his renewed hopes for the liberal cause. "Shelley's discussion of the prophetic spirit, not of common sense precisely, but of poetry in general, must have buoyed Hunt's spirits for the task he was undertaking. Shelley optimistically describes an inevitable progress in human society and human morality led by and expressed by the poets:

[The poets] are not only the authors of language and of music; ... they are the institutors of laws, and founders of civil society, and the inventors

\footnotetext{
${ }^{8}$ Fogle, p. 124

${ }^{9}$ Amy Lowell, John Keats, 2 vols. (New York, 1925), 1:136, quoted by James B. Misenheimer, Jr., in "Leigh Hunt: a 'Great Introducer' in English Romanticism," Yearbook of English Studies, 1 (1971): 135

${ }^{10}$ James B. Misenheimer, Ir., "Leigh Hunt: A 'Great Introducer' in English Romanticism," Yearbook of English Studies, 1 (1971): 138.

11 Though Hunt's arrival in Italy was delayed till 1822, he began serious plans for emigration in the summer of 1821. In letters of July and August between himself and Shelley, the first details of the scheme can be followed: The Correspondence of Leigh Hunt edited by His Eldest Son, 2 vols. (London: Smith, Elder and Co., 1862), 1 : 163-169. Though Shelley's "Defence of Poetry" was not finally published for several years, Hunt became aware of it about this time. Details are given by Bruce R. McElderry, Jr., ed., Shelley's Critical Prose (Lincoln: University of Nebraska Press, 1967), pp. 3-4.
} 
of the arts of life, and the teachers, who draw into a certain propinquity with the beautiful and the true, that partial apprehension of the agencies of the invisible world which is called religion. . . . Poets . . . were called, in the earlier epochs of the world, legislators or prophets; a poet essentially comprises and unites both these characters. For he not only beholds intensely the present as it is, and discovers those laws according to which present things ought to be ordered, but he beholds the future in the present, and his thoughts are the germs of the flower and fruit of latest time. ${ }^{12}$

The special appeal such a passage would have for Hunt is its sense of a powerful sweep of society forward into ever better institutions, manners, and enjoyments, precisely the sort of movement that he too served as a liberal editor and man of letters. To be associated in this kind of constructive activity with two of the most powerful poets of his time was the purpose of his emigration to Italy.

Because Leigh Hunt's knowledge of Shelley's and Hazlitt's theoretical essays was so close and so basic to his own critical attitudes, some further attention to the details of their thought will help place Hunt's contribution to romantic criticism in its proper frame. In Shelley's "Defence of Poetry," "imagination"-that workhorse term of romanticismrefers to a class of mental actions that compose from individual thoughts, "as from elements," other more complex thoughts which are synthesized integrities or unities. Poetry is defined as "the expression of the imagination" or, in other words, as the creation or synthesis of these unities. Furthermore, "poetry is connate with the origin of man," because to be human means to engage in the process of perceiving or constructing these unities. In a lyrical but completely empirical formulation that John Locke would not have disagreed with, Shelley states, "Man is an instrument over which a series of external and internal impressions are driven." This experiential process is delightful, and the child or the primitive man will try to express in voice and gesture both its delight and its shaping of these impressions into the most comprehensive unities possible. And indeed as the experiential impressions fade, he will try to prolong them by those expressions he has associated with them. These expressions constitute the products and history of the poetic or synthesizing spirit. At the earliest stages man delights in the external world; then comes self-consciousness, social consciousness, and finally civilized societal awareness. At each stage imagination strives to create those unified expressions of experience that assure the keenest delight: "For there is a certain order or rhythm belonging to each of these classes of mimetic representation from which the hearer and the spectator receive an intenser

\footnotetext{
${ }^{12}$ Bruce R. McElderry, Jr., ed., Shelley's Critical Prose (Lincoln: University of Nebraska Press, 1967), p. 7.
} 
and purer pleasure than from any other: the sense of an approximation to this order has been called taste by modern writers." (Hazlitt, we have seen, had used the word taste, or its synonyms tact and finesse, in his description of Hunt.)

In the earliest stages of human development, Shelley continues, every individual can express this order well. Shelley rather cumbersomely calls this power of expression the "faculty of approximation to the beautiful." As time goes on some persons are recognized to possess the faculty to a much higher degree than others, and to them is granted the specialized task of expressing the fundamental human order most fully so that "the pleasure resulting from the manner in which they express the influence of society or nature upon their own minds, communicates itself to others, and gathers a sort of reduplication from that community." The poets, in other words, are those who express the truest vision of humanity-the most comprehensively integrated and the most accordant with "pleasure." And this vision the rest of society receives and assimilates to itself. Thus it is that the poets, "who imagine and express this indestructible order," become the institutors, the founders, the teachers, and the prophets. ${ }^{13}$ For Shelley, then, the poets are practical people of thought and action leading forward the evolutionary march of human knowledge and institutions. And when we are looking for sources of Leigh Hunt's literary principles we might remember this essay. Shelley, a true genius, provided a coherent, rational structuring of literary principles, including answers to those questions that occupied several of the greater romantic writers: what is a poet? and what does a poet do? And to this structure, in part, Leigh Hunt, a man of taste and common sense, assimilated his own thought. If we accept this view of the matter, we can get a little closer to understanding what quality Hunt possessed that enabled him to be the great discoverer, nurturer, and introducer of literary genius to his age. Remember again Shelley's remark: "There is a certain order or rhythm belonging to each of these classes of mimetic representation, from which the hearer and spectator receive an intenser and purer pleasure than from any other: the sense of an approximation to this order has been called taste by modern writers."

Let us turn now to the essay by Hunt's other great critical friend, who commended him for his "fineness of tact and sterling sense." Begin again with the passage from "On Genius and Common Sense" quoted earlier. "Tact, finesse, is nothing but the being completely aware of the feeling belonging to certain situations, passions, \&c. and the being consequently sensible to their slightest indications or movements in

${ }^{13}$ Ibid., pp. 4-7. 
others." ${ }^{14}$ Iust as Shelley did, Hazlitt bases his model of human experience and thought in "feeling," or what the British empirical philosophers called impression. He says, "In art, in taste, in life, in speech, you decide from feeling, and not from reason; that is, from the impression of a number of things on the mind, which impression is true and well-founded though you may not be able to analyse or account for it in the several particulars" [my emphasis]. A little further on he calls these impressions "the immediate stamp of nature." The single or unified impression that results from "the impression of a number of things" clearly involves a synthesis of many elements into an integrated experience which includes a power to respond, express, or, as he says, "judge." Hazlitt elaborates more fully upon the power of judgment and expression at the level of ordinary experience, the level he calls "common sense." "Common sense is the just result of the sum-total of such unconscious impressions in the ordinary occurrences of life, as they are treasured up in the memory, and called out by the occasion. Genius and taste depend upon much the same principle exercised on loftier ground and in more unusual combinations." 15

"Common sense" for Hazlitt is a powerful and firm guide to action. It is the "just result" of "the sum-total" of the unconscious impressions that constitute experience. Common sense, then, is accurate human feeling, directly representative of a pure humanity uncontaminated by prejudice, false refinement, or vulgar opinion. It is easily tainted, but in persons of genuine tact or finesse it can function as "the prophetic spirit of common sense." And it is on the basis of this common sense that loftier acts of genius or taste occur. Hunt stood between Hazlitt and Shelley, these literary men of genius, highly regarded by both for powers of taste and judgment, remarkable because grounded in a pure and honest common sense. As a critic, editor, and representer of ideals they believed in, according to their own testimony, these men found none more capable of understanding and supporting them-and their genius-than Leigh Hunt.

To follow this last point a little further, let us consider Hazlitt's other term. If Hunt is exemplary of common sense, fineness of tact, indeed "sterling" sense, what is it that sets "genius" apart? Hazlitt says the man of real genius "has the feeling of truth already shrined in his own breast, and his eye is still bent on nature to see how she expresses herself." ${ }^{16}$ Based on his own self-awareness, his own experience of the fundamental human order, the man of genius looks for accordant expres-

\footnotetext{
14 Nabholtz, p. 30

15 Ibid., pp. 18-19

${ }^{16}$ Ibid., p. 29.
} 
sions on the part of nature herself. But the man of common sense does this too, does he not? How else could he regard her but in the light of his fundamental interpretive finesse or tact unless it be with something less appropriate, like prejudice or vanity? The difference, then, is that the man of genius creates new relationships with nature which common sense never realized before. "Genius or originality is, for the most part, some strong quality in the mind, answering to and bringing out some new and striking quality in nature [Hazlitt's emphasis]." 17 Apparently the "prophetic spirit" of common sense in some persons of extreme capacity, which sets them over into a new category of intellect, can enter or realize uncharted territories of internal or external nature and thus open them more fully to experience. What genius discovers, once revealed, is available to all persons of common sense. Those persons, however, do not merely passively receive what genius has given them. Rather they themselves, having been shown the way, must positively reenact the discovery, extending by imagination their own stores of passion or feeling into the revealed area of experience.

The creations of imagination, syntheses of various impressions, organize themselves for Hazlitt around particular strong passions, not according to structured forms: "[In acts of association] any impression in a series can recall any other impression in that series without going through the whole in order: so that the mind drops the intermediate links, and passes on rapidly and by stealth to the more striking effects of pleasure or pain which have naturally taken the strongest hold of it." 18 The organizing nodes of mental syntheses, in Hazlitt's view, are not rational, esthetic, or logical arrangements and structures of impressions, but rather strong predominating passions, elemental in force, to which all other impressions are drawn, as to a magnet.

A key point to be observed in Hazlitt's critical theory is that imagination belongs as well to the person of common sense, the person of taste, and the person of genius. Imagination, based on feeling, responsive to external and internal impressions according to the modes of a fundamental human order of experience, is the power that communicates between them. And the fact that imagination operates throughout the scale of cognition from the just-awakening common sense to the loftiest genius means that a common instrument for expression or communication exists whereby the discoveries of genius can be assimilated into the community at large; and, thus, the liberal march of progress is effected. If the geniuses are the innovators and leaders of moral, cultural, or artistic reform, persons of reliable common sense are needed to consolidate and establish

17 lbid.. p. 31.

18 Ibid., p. 22. 
the reformation. Shelley recognized in Leigh Hunt such a person and invited him to Italy on that basis. ${ }^{19}$

This essay has devoted considerable space to reviewing fundamental critical principles expressed by two romantic creators who were closest to Hunt during, probably, the most crucial year of his life. One reason to conduct such a review, is that Hunt's intelligence and critical reputation have been attacked by influential scholars who have not considered the relevant context, but instead have denigrated his work because it has not explicated Coleridge. In fact, the primary elements in Hunt's critical principles owe far more to Hazlitt and Shelley, whom he assimilated and represented to the general reading public. A second reason for reviewing Shelley and Hazlitt, especially the latter, is that they define a process, as it were a social program of art at its highest levels of influence over the progressive tendencies of humankind, which explains precisely what Hunt's position and what his work amounted to in the romantic scheme of things. Hazlitt's depiction of genius and common sense provides the clearest model of what we may assume Hunt's relation to his greater contemporaries to be. It is a model which explains in more detail and gives significant depth to the character Amy Lowell gave us of Hunt as "a great introducer." Hunt had a power of taste, in the high sense defined by Shelley and Hazlitt, that was effective in its own time and can still instruct in its own right, and complete our awareness of that splendid age of literary art. ${ }^{20}$ Let us consider an example.

Before turning to one of Hunt's best pieces of practical criticism, let us address Hazlitt's mild censure of his writing in The Spirit of the Age: "he perhaps takes too little pains, and indulges in too much wayward caprice." This applies to much of Hunt's vast production as a literary journalist, and it has been made the occasion for critical abuse and ridicule. But we need to focus on his best work, as we do for the greater geniuses of his age. A "balanced" judgment of Wordsworth would reveal that the volume of his mediocre verse exceeds that of his irreplaceable

\footnotetext{
${ }^{19}$ An excellent full picture of Hunt's relation to Shelley as co-worker in the liberal cause is the selection from both authors' publications and correspondence, edited and discussed by R. Brimley Johnson, Shelley-Leigh Hunt: How Friendship Made History: Extending the Bounds of Human Freedom and Thought (New York: Haskell House, 1972-reprint of 1929 edition).

${ }^{20}$ Corroborating evidence of the need felt among the romantics for cultivating and enlightening public taste to the new literature is in Wordsworth's "Essay, Supplementary to the Preface" (1815), which Hunt surely knew. "If there be one conclusion more forcibly pressed upon us than another by the review which has just been given of the fortunes and fate of poetical Works, it is this,--that every author, as far as he is great and at the same time original, has had the task of creating the taste by which he is to be enjoyed: so has it been, so will it continue to be." William Wordsworth: Selected Poems and Prefaces, ed. Jack Stillinger (Boston: Houghton Mifflin Co., 1965), p. 477. Like all the greater poets of his day, Wordsworth thought himself ill-served by criticism in the major literary revicws.
} 
poetry by a considerable margin. And the same proportion would exist for Byron and many other writers. Indeed Hunt himself remarks on this general fact in his discussion of Middleton, Dekker, and Webster in Imagination and Fancy (1844): "When about to speak of these and other extraordinary men of the days of Shakespeare ... I wasted a good deal of time in trying to find out how it was that, possessing, as most of them did, such a pure vein of poetry ... they wrote so much that is not worth reading, sometimes not fit to be read. I might have considered that, either from self-love, or necessity, or both, too much writing is the fault of all ages and of every author." 21 This is not the only place in Hunt's writings where he intimates a shortcoming of his own in this regard. But there are many examples where the trenchancy of his style and the vigor of his common sense combine with delightful effect.

The example we turn to, recalling Hazlitt's distinction between common sense and vulgar opinion, is Hunt's defense of the unconventional genius of Byron's Don Juan against its canting, hypocritically moral detractors. In The Examiner of October 31, 1819, he writes, "Don Juan is accused of being an 'immoral' work, which we cannot discover." $\mathrm{He}$ describes the situation in Canto I leading to the mutual seduction of Juan and Julia. "This, it is said, has tendency to corrupt the minds of 'us youth,' and to make us think lightly of breaking the matrimonial contract. But if to do this be immoral, we can only say that Nature is immoral." He goes on, "Lord Byron does no more than relate the consequences of certain absurdities. If he speaks slightingly of the ties between a girl and a husband old enough for her father, it is because the ties themselves are slight. He does not ridicule the bonds of Marriage generally, or where they are formed as they should be: he merely shows the folly and wickedness of setting forms and opinions against nature." Clearly Hunt is speaking with the insight of unblemished common sense, as Hazlitt discussed it, and from this base is opening to his readers the opportunity to respond justly to the work against the conventionally antisexual morality that was already forming this early in the nineteenth century. In fact, with a clearheaded awareness of powerful forces within human nature that William Blake would not have disdained, Hunt wittily attacks the moralists straight on.

There are a set of prudish and very suspicious moralists who endeavor to make vice appear to inexperienced eyes much more hateful than it really is. They would correct Nature; - and they always overreach themselves... Now the said prudes ... are constantly declaiming on the deformity of vice, and its almost total want of attraction. The consequence is, that when they are found to have deceived (as they always

\footnotetext{
${ }^{21}$ Leigh Hunt, Imagination and Fancy (New York: G. P. Putnam, 1848), p. 158.
} 
are) and immoral indulgence is discovered to be not without its charms,- the minds of young persons are apt to confound their true with their false maxims.

Because Hunt's stand here-for common sense and for human naturelinks him with several of the great geniuses of his age, notably Shelley and William Blake as well as Byron, it is worth quoting a little further from this review. Lacking an independent income, having many children to feed, entirely dependent on an accepting public for his maintenance, Hunt shows courageous fidelity to the standards of common sense as well as a keen, "prescient" anticipation of the long-running history and resolution of this issue. Discussing Canto II, Hunt says,

We suppose there has been some sermonizing on the description of the delight arising from the "illicit intercourse" of Juan and Haidee. People who talk in this way can perceive no distinctions.

He goes on to describe briefly the circumstance of those lovers, removed from the artificial constraints of society. Then,

But what is there to blame in a beautiful and affectionate girl who gives way to a passion for a young shipwrecked human creature bound to her by gratitude as well as love?... Does she not receive, as well as bestow, more real pleasure (for that is the question) in the enjoyment of a first and deep passion, than in becoming the wife of some brother in iniquity to whom her pirating father would have trucked her for lucre?

The ironic cadences of that last sentence cut to the bone, not merely as wit but as incisive criticism of social sickness in his age. Hunt interprets Byron more deeply perhaps than Byron intended. In a sense, Hunt extends Byron's poem to a level of application that the apparent levity and flippancy of Byron's tone might not otherwise reach with the general reader. Hunt reveals in Byron that which Byron's tone might have concealed. Finally, the concluding paragraph of Hunt's review is surely an example of tact and finesse yielding "the prophetic spirit of common sense." It is short, but to students of romanticism it cannot but suggest the struggles of Los with Vala in The Four Zoas or of Los with his Spectre in Jerusalem, which Blake was working out at the very time Hunt was writing. Here is the paragraph.

The fact is, at the bottom of all these questions, that many things are made vicious, which are not so by nature; and many things made virtuous, which are only so by calling and agreement: and it is on the horns of this self-created dilemma, that society is continually writhing and getting desperate. ${ }^{22}$

${ }^{22}$ Leigh Hunt, "On Byron's Don Juan: Cantos First and Second," The Examiner 618 (Oct. 31, 1819); reprinted in Anthology of Romanticism, ed. Ernest Bernbaum (New York: The Ronald Press, 1948), pp. 1003-05. 
For another exhibit of Leigh Hunt's role as romantic critic, let us turn to his only extended effort at theoretical exposition, the essay "What Is Poetry?" which opens the 1844 volume Imagination and Fancy. This essay has been most severely-and strangely-denigrated by scholars in the past quarter century. The negative estimates concerning Hunt's intelligence and critical achievement quoted at the beginning of this discussion are directed mainly at the 1844 essay. The essay has received more mockery than sympathetic reading in recent years. Ernest Bernbaum in 1929 called it "one of the clearest and most comprehensive, though not the profoundest, treatment of the subject by any of the Romantics." 23 But M. H. Abrams wittily set the tone for contemporary reception of the essay by reminding his readers of a critical joke made at Hunt's expense in the previous century. After summarizing differences between Coleridge, Hazlitt, Shelley, and Byron in the definition of poetry, Abrams quips, "Finally Leigh Hunt reconciled these differences by the simple device of a definition which, as David Masson has remarked, is 'constructed on the principle of omitting nothing that anyone would like to see included'." 24

It seems to have been the elaborateness of Hunt's opening definition that has led his detractors to deny him judgment or distinction of mind. Yet it seems to me that if one reads his opening paragraph, keeping in mind the relevant background of Hazlitt, Shelley, and the other great critical geniuses of the era, one may well be enlightened, pleased, and indeed impressed by the distinguished qualities of mind revealed. Hunt gives an imaginatively integrated account of romantic poetic theory that begins with a lucid, tightly structured outline, that is developed with clarity and cogency, and that ends with a fruitful juxtaposition of passages from Milton, Coleridge, and Shelley, which resonate with new significance in the context he has prepared for them. Perhaps by 1844 the principles expressed are no longer revolutionary. But neither are Hunt's intentions revolutionary. They are, rather, "to furnish such an account, in an essay, of the nature and requirements of poetry, as may enable readers in general to give an answer on those points to themselves and others" [Hunt's emphasis]. ${ }^{25}$

Turning to the essay, one discovers that Masson's and Abrams's word is not precisely accurate. The paragraph in question is not a "definition" according to the meaning by which one expects a man of abstract thought

\footnotetext{
${ }^{23}$ Bernbaum, p. 1216. The first edition of his anthology appeared in 1929.

${ }^{24} \mathrm{M}$. H. Abrams, The Mirror and the Lamp: Romantic Theory and the Critical Tradition (New York: W. W. Norton, 1958), p. 49. Abrams is quoting David Masson, Wordsworth, Shelley, Keats and Other Essays (London, 1874).

${ }^{25}$ Imagination and Fancy, p. viii.
} 
to summarize a topic or concept broadly and memorably in a short pithy expression. Rather, Hunt's paragraph is an announcement and outline of the aspects of his subject to be covered at length in the essay, all brought together in a connected, if full, statement of his intent (current academic rhetoricians call such a passage occurring at the beginning of an essay the thesis statement). Indeed Hunt's 1844 essay might seem to lack the lightning flashes of genius used by the romantic essayists, but Hunt's procedure ably organizes for the wider, though educated Victorian reading public the complex theories of the romantic innovators.

Here is the opening statement of "What Is Poetry?"

Poetry, strictly and artistically so called, that is to say. considered not merely as poetic feeling, which is more or less shared by all the world. but as the operation of that feeling such as we see it in the poet's book, is the utterance of a passion for truth, beauty, and power, embodying and illustrating its conceptions by imagination and fancy, and modulating its language on the principle of variety in uniformity. Its means are whatever the universe contains; and its end, pleasure and exaltation. Poetry stands between nature and convention, keeping alive among us the enjoyment of the external and spiritual world: it has constituted the most enduring fame of nations; and next to Love and Beauty, which are its parents, is the greatest proof to man of the pleasure to be found in all things, and of the probable riches of infinitude. ${ }^{26}$

Every point that Hunt develops in the 46 pages of his essay is touched on in this outline, and the transitions he will develop in full are intimated. Each of the topics can be paralleled in an important precursor essay by Wordsworth, Coleridge, Hazlitt, Shelley, or others, but Hunt richly illustrates each and treats it with his own taste and good sense. Notice the opening distinction between poetry as the actual expressions in the poet's book and a more general poetic feeling "which is more or less shared by all the world." This has been regarded by Stephen F. Fogle, among others, as so much soft and meaningless verbiage padding out an already overblown statement. ${ }^{27}$ Although "general poetic feeling" is a concept easily and often sentimentalized. Hunt is making an important point here, one already commented on in relation to Shelley's "Defence of Poetry." Hunt wishes to insist that what the poets express in their

\footnotetext{
26 Ibid., p. 2.

${ }^{27}$ Stephen F. Fogle's essay, noted earlier, mocks nearly every phrase in this outline. Fogle misses the fact that it is an outline rather than a definition, and thus is led into an unsympathetic reading of each phrase without, apparently, awareness of its context. He says, "The very piling up of terms in this passage has worn them threadbare. That they are all set down here together, that it is this cluster of words rather than another, is proof that something has happened in the world of criticism since 1800" (p. 131). Something has happened, to be sure, something positive. The ideas have made their way into the world of common sense, perhaps with their edges softened but not with their shapes deformed, at least not in Hunt's essay as it is subsequently developed. Rene Wellek, whose damning estimate of Hunt's intel-
} 
books is not foreign, alien, effeminate, or imaginary. ${ }^{28}$ Rather, poets express a fundamental human order shared by all members of the species, an order expressible with greatest comprehensiveness and pleasurableness by the best poets in their achievements of greatest truth and beauty.

The concepts of truth and beauty, as well as two others equally important to Hazlitt and Shelley, are referred to then in the section of Hunt's outline that might properly be singled out as the "definition." The more limited "definition" reads "Poetry ... is the utterance of a passion for truth, beauty, and power." Each of these key terms receives further elaboration.

- "Poetry is a passion, because it seeks the deepest impressions; and because it must undergo, in order to convey them." The poet must feel, and feel deeply, the myriad impressions that nature and his own responses play across his sensibility. He must willingly undergo these feelings if he is genuinely to register and thus be able to express truly the fundamental human order.

- - It is a passion for truth, because without truth the impression would be false or defective." "Truth" here means an accurate registration of the realities of nature. In Hazlitt's terminology it would involve the distinction between common sense and vulgar opinion. The passion for truth, for instance, is what Hunt showed to be operative in Byron's attack on hypocritical moralities in his review of Don Juan.

- It is a passion for beauty, because its office is to exalt and refine by means of pleasure, and because beauty is nothing but the loveliest form of pleasure." Hunt is referring here to Shelley's notion of beauty as the degree of expression approximating most closely to the fundamental order or rhythm of experience from which, accordingly, the purest and most intense degree of pleasure ensues. Thus he calls it the "loveliest," meaning the most desirable, the most pleasing form of pleasure. It must be remembered also that, in his time, Hunt would need to distinguish by some such adjective the pleasure he is discussing because of the

ligence (noted earlier) shares Fogle's unsympathetic mocking approach, also seems to ignore the larger structure and interrelated coherence of Hunt's essay. Neither critic recognizes that the essay belongs to the new Victorian genre, the "organized," unified, tightly structured, serious prose essay. Here are not the rambling, intuitively guided series of observations that appear in Hazlitt's writing, for instance, but a consciously structured meditation enjoying intellectual coherence and rational orderliness. It is indeed of the Victorian age of consolidation and not of the bounds-breaking, revolutionary, expansive fervor of the century's earlier decades. But Fogle and Wellek are wrong to see the essay as muddle-headed or degenerate.

${ }^{28}$ Contrast Hunt's desire with Matthew Arnold's summarizing characterization of Shelley many years later as "A beautiful and ineffectual angel beating in the void his luminous wings in vain" (Essays in Criticism, 1888). Arnold's phrase is very amusing and eternally memorable, but it also did a good deal of damage to the reputation of poetry among the middle class reading public that Hunt is reaching out to in his essay. 
Benthamite Utilitarian scheme to reduce all pleasures to the same qualitative level.

-Finally, "It is a passion for power, because power is impression triumphant, whether over the poet, as desired by himself, or over the reader, as affected by the poet." Only by feeling deeply, by "ardent subjections of one's self to emotion" can one realize the pleasure, the beauty, the truth, and so on. In a way this axiom repeats the earlier three, but by stating it in this form, Hunt is able to recall Hazlitt's doctrine that the synthesis or ordering of experience, poetry triumphant, occurs across the nodes of most intense feeling or impression.

These few passages, I believe, illustrate how vividly Hunt's essay picks up and redeploys the concepts of his great precursors. One or two further comments must suffice for this demonstration. Hunt's discussion of imagination and fancy has been much discussed by Wellek, Fogle, Thompson, and others, who do or do not believe he knew what he was talking about. Those who think he did not know insist that he was trying to explain Coleridge but could not. I would simply agree with James R. Thompson that in the distinction he makes between the two terms, "It is more likely ... that Hunt's reference is to the preface of Wordsworth's 1815 edition in which he attempts to justify his classifications" 29 than it is to Biographia Literaria, especially the fragmentary remarks of chapter 13. To me, Hunt's discussion of imagination and fancy is sufficiently compatible with Wordsworth's to demonstrate a reasoned and intelligent position on his part rather than the dim-witted pretense at understanding implied by Wellek.

One further example: Fogle is remarkably disturbed by Hunt's mention of love and beauty in the final clause of his outline. Fogle writes, "To make Poetry the child of Love and Beauty ... is to create a family group that defies analysis.... One would like to ask what the exact qualities of Love and Beauty are that are reproduced in their child Poetry." 30 The answer to Fogle is rather simple. Hunt has claimed that poetry "is the greatest proof to man of the pleasure to be found in all things, and of the probable riches of infinitude." This is easy enough to interpret in the light of poetry's relation to the fundamental order of experience between man and nature. Maybe the phrase "probable riches of infinitude" refers to transcendent implications, like Wordsworth's "Intimations of Immortality"; but that need not concern us for the present. Hunt also says, however, that two qualities, love and beauty, are even greater proofs of these felicities than poetry is, and furthermore, it is

\footnotetext{
${ }^{29}$ Thompson, p. 108.

${ }^{30}$ Fogle, pp. 131-2.
} 
apparently these greater qualities that by their conjunction give birth to poetry. This is the assertion that has confused.

The discussion so far concerning the meaning of "Beauty" for Hunt and Shelley explains how she might be called the giver of felicity and the mother of poetry. But how does "Love" enter the picture? Realizing that we are reading the last clause of Hunt's topical outline for his essay, if we turn to the last topic developed, we find another quotation from Shelley's "Defence of Poetry," wherein the bridegroom appeareth. ${ }^{31}$ The first part of the quoted passage alludes again to the progressive recovery of the beauty of existence through poetic expressions which use external nature to reveal the exalted humanity of our interior spirit: poetry represents or "impersonates" objects, which then stand as "memorials of that gentle and exalted content"-human feeling and human being-"which extends itself over all thoughts and actions with which it co-exists." It is also notable that this part of Shelley's paragraph describes the activity of the poet himself, the maker of the book proper which Hunt distinguished in the opening phrases of his essay. Reading on into the second half of the quoted passage, we see that "Love" is the new concept introduced. Additionally, it becomes apparent by the last sentence of the passage that the perspective has shifted away from the poet who makes the book to the reader of the book, the receiver of the effects of poetry, which are explicitly stated in this instance to be moral in character. In commenting on his choice of this passage, Hunt calls it a "peroration." As a good Latinist Hunt would know that the basic meaning of the word is not simply a fancy passage of prose, but the concluding rhetorical summation of the primary point of a discourse. But in fact the passage is not, in Shelley's "Defence," the peroration. It comes from the early middle of the essay and is merely one among a number of parallel ideas. But the passage is Hunt's peroration. By his selection and placement of Shelley's paragraph, he makes it the rhetorical conclusion of his own essay. He assimilates his thought to it and ties conclusively together the various threads of his critical exposition.

Here is the second part of the passage.

The great secret of morals is love, or a going out of our own nature, and an identification of ourselves with the beautiful which exists in thought, action, or person, not our own. A man, to be greatly good, must imagine intensely and comprehensively; he must put himself in the place of another, and of many others: the pains and pleasures of his species must become his own. The great instrument of moral

${ }^{31}$ Imagination and Fancy, p. 47. McElderry, pp. 12-13. The passage quoted begins with the words "Poetry lifts the veil from the hidden beauty of the world. ..." 
good is imagination; and poetry administers to the effect by acting upon the cause.

Though Shelley's expression of his critical genius is compact and intense, it can be explicated simply enough. Love, he says, is a going out from our own selfish nature to an identification of ourselves with the beautiful, which, as we know by now, is the most intense and comprehensive realization of the fundamental order. The instrument of this going out and identification is the imagination, or that capacity of the mind whereby "true" and "beautiful" syntheses of our impressions are achieved. At first, poetry expresses the imagination of the poet, the man of genius; but, equally important, once expressed by genius, the poetry affects the imagination of the man of common sense, causing his basic humanity to go beyond its personal embodiment to awareness of unity-identification-with the universal order of humanity.

Hunt has chosen a complex passage from Shelley to stand as his summation, but his choice reveals deep critical insight and an editor's keen skill as he incorporates the passage and its reverberations with his own ideas. The dual perspective of the paragraph as it shifts from poet to reader reenacts the passage of insight from genius to common sense. In the first half of the passage the poet extends his own humanity, his own sense of fundamental order, out to nature to represent or "impersonate" it and make it partake of this order. Then, as described in the second half of the passage, the reader recognizes his own deepest self in this impersonation of nature and other beings. Thus not only is that deepest self evoked, but it is also extended into imaginative identification-love-with the order (the beautiful) in persons not himself. Because of this identification—at the deepest level of common humanity - benevolence, goodwill, tolerance, and so forth, the profoundest acts of moral good are brought about. Poetry achieves this end by acting upon the cause of this end, which is, simply, the imaginative perception of beauty or fundamental order.

There is another sense of the word love evoked in Hunt's quotation from Shelley that goes beyond the ideal of imaginative identification with the fundamental order of beauty. In distinguishing between beauty and love, Hunt overleaps the kind of dangerous aestheticism or solipsistic indulgence which might rest satisfied in a "Palace of Art" (a topic written on by Tennyson in his poem of that name first published in 1832 and in revised form in 1842, respectively twelve and two years before Hunt's essay appeared). Hunt emphasizes instead the active progression in knowledge and being that accords with his liberal social hopes for mankind. The two words depict a staged response to perception of the fundamental human order. The first stage is simply the most comprehensive and pleasurable apprehension of this order, experienced as beauty. The 
second stage, however, is the sense of this beauty made self-conscious and active. This is the stage called love. Relatively speaking, beauty might be experienced in a passive or receptive mode of pure delight-a passion and hence a power, but a quiescent, inwardly absorbed one, perhaps not even fully cognizant. But love, more self-conscious and explicitly active in its association with moral good, as Shelley's passage stipulates, unites itself with the quieter state. And the union of quiescent receptive power with active outgoing power, both emanating from perception of the fundamental human order, results in a new birth of expression, a new utterance of the fundamental order-or a new utterance of power, passion, truth, and beauty, which we recall was Hunt's basic definition of poetry. Keeping in mind the dual aspect of imagination that Hunt evoked by selecting this particular passage from Shelley's essay, involving both the reader of the poem and its maker, let us note that the utterance or expression of the reader will be active and moral whereas the utterance of the poet proper will be cognitive and verbal. It is in this rich sense that Hunt refers to poetry as the child of love and beauty.

Hunt's formulation, then, is another redeployment of the powerful romantic concepts concerning poetry, art, and social responsibility created by his great precursors. His is not so complex as their fuller analyses, but neither does it merely mimic, nor does it distort in its greater simplicity. His remarks resonate with theirs. Is this resonance absolutely essential to our understanding of romantic literary theory? Rationally, perhaps it is not. But romantic literary theory emphasizes other qualities than the coldly rational. It cares for pleasure, taste, and passion, too. And the pleasure of knowing Leigh Hunt at his best and appreciating his intelligence, his taste, and his passion for literature, just as his great contemporaries knew and appreciated it, is available to us still in his finer work. It is integral to the even richer pleasure of knowing the era we recall as the romantic age of genius and common sense. 